\title{
ОСВІТНЯ ТЕХНОЛОГІЯ “МЕТОД ПРОЕКТІВ”: СТАН РОЗРОБКИ В НАУКОВО-МЕТОДИЧНІЙ ЛІТЕРАТУРІ
}

\author{
О. П. Корнійчук, Л. М. Бурова
}

Львівський національний медичний університет імені Данила Галицького

\section{EDUCATIONAL TECHNOLOGY "THE METHOD OF PROJECTS": STATE OF DEVELOPMENT IN SCIENTIFIC AND METHODOLOGICAL LITERATURE}

\author{
O. P. Korniychuk, L. M. Burova \\ Lviv National Medical University by Danylo Halytskyi
}

\begin{abstract}
Стаття розкриває становлення освітньої технології, а саме “метод проектів” як один із методів інтерактивного навчання.
The article adduces the formation of educational technology, especially "The method of projects" as one of the methods of interactive learning.
\end{abstract}

Вступ. Основною вимогою, яка висувається сьогодні до якості медичної освіти в умовах конкуренції на світовому ринку медичних послуг, $є$ необхідність навчити майбутніх лікарів реалізувати отримані знання з використанням набутих упродовж років навчання теоретичних і практичних знань 3 клінічних дисциплін на базі глибоких медико-біологічних знань. Зростання обсягу інформації, яку має засвоїти студент, потребує застосування якісно нових технологій навчання, які, з одного боку, мають сприяти інтенсифікації праці студентів, а з іншого - підвищувати ефективність засвоєння цієї інформації без переобтяження інтелектуальних можливостей.

Професійна спрямованість сучасної освіти, особливо у вищій медичній школі, повинна мати особистісно-орієнтований підхід. Важко створити переконливий алгоритм для виявлення тієї особистості, яка у майбутньому стане справжнім фахівцем, лікарем за покликанням, дослідником, науковцем. Одним із способів, який дасть змогу розпізнати, розкрити, підтримати і створити оптимальні умови для розвитку такого фахівця, $є$ метод проектів (від латинського projectus - “кинутий вперед").

Основна частина. Метод проектів уперше був запропонований американським філософом і педагогом Дж. Дьюї, а також його учнем В. Х. Кілпатріком на початку XX сторіччя. Метод є особливим видом інтелектуальної діяльності, характерні риси якої-самостійний пошук необхідної інформації, ііі творче пе- ретворення в матеріальний продукт. Цей метод має на меті надання можливості самостійного отримання знань. У проектній методиці завдання викладача полягає у консультації та коригуванні діяльності студентів [1]. В. Х. Кілпатрік дав йому таке визначення: "Метод проектів - це метод планування доцільної (цілеспрямованої) діяльності у зв'язку з вирішенням певного навчально-виховного завдання в реальній життєвій обстановці".

Метод проектів - це багатовекторна методика, котру можна характеризувати як: 1) спосіб організації пізнавально-трудової діяльності з метою вирішення проблем, пов'язаних із проектуванням, створенням і виготовленням реального об'єкта (продукту праці) [2]; 2) спосіб організації педагогічного процесу, основою якого є взаємодія педагога з вихованцем і оточуючим середовищем під час реалізації проекту - поетапної практичної діяльності для досягнення поставлених завдань [3]; 3) спосіб організації пізнавально-трудової діяльності, який передбачає визначення потреб людей, проектування продукту праці відповідно до цих потреб, виготовлення виробів чи надання послуг, оцінку якості, визначення реального попиту на ринку послуг [4]; 4) особистісно-орієнтований метод навчання, заснований на самостійній діяльності щодо розробки проблеми й оформлення іiі практичного результату [5]; 5) самостійна творча праця (від пропонування ідеї до втілення іiї у готовому виробі), яка виконується під контролем і за

() О. П. Корнійчук, Л. М. Бурова 
безпосередньої консультативної допомоги викладача [6]; 6) сукупність навчально-пізнавальних прийомів, які дають змогу вирішити ту чи іншу проблему в результаті самостійних дій з обов'язковою презентацією [7], 7) оволодіння певними практичними або теоретичними знаннями, тією чи іншою діяльністю [3]; 8) комплексний узагальнюючий процес раціонального сполучення репродуктивної та продуктивної діяльності, який дає змогу комбінувати і поєднувати формальні знання $з$ практичним досвідом [8]; 9) система навчання, за якої знання набуваються у процесі планування та виконання завдань-проектів, які поступово ускладнюються [9]; 10) гнучка модель організації навчального процесу, орієнтована на творчу самореалізацію особистості, завдяки розвитку іiі інтелектуальних і фізичних можливостей, вольових якостей і творчих здібностей у процесі створення під контролем викладача нових товарів і послуг, які мають суб' єктивну або ж об' єктивну новизну, а також практичну значущість [10]; 11) форма організації навчання, яка полягає в тому, що самі студенти визначають собі певні практичні завдання (проекти) і у процесі їх виконання здобувають знання та набувають навичок (Н. Ничкало) і яка передбачає комплексний характер діяльності всіх учасників 3 метою отримання освітнього продукту за певний проміжок часу [11]; 12) знання і навички набуваються у процесі планування й використання практичних завданьпроектів [12]; 13) спеціально організований комплекс дій для самостійного виконання, самостійного прийняття рішення і відповідальність за свій вибір, результат праці та створення продукту [13]; 14) організований викладачем підхід до навчання у співробітництві, за умов якого студенти набувають і використовують набуті знання та вміння для вирішення реалістичних проблем у процесі грунтовного дослідження [14]; 15) педагогічна технологія, орієнтована не на інтеграцію фактичних знань, а на їх застосування для набуття нових (інколи і шляхом самоосвіти) [15], що передбачає певну сукупність навчально-пізнавальних прийомів, які дають змогу розв’ язати ту чи іншу проблему в результаті самостійних дій з обов'язковою презентацією цих результатів [16]; 16) сукупність педагогічних прийомів і операцій, які здійснюються викладачем і студентами у процесі особисто значущої діяльності з метою активізації пізнавальних інтересів студентів, що спрямовані на отримання та закріплення нових знань, умінь і навичок, розвиток творчих здібностей і набуття досвіду практичного розв' язання самостійно поставлених завдань [16]; 17) спільна діяльність викладача та студентів, яка спря- мована на пошук вирішення проблеми, проблемної ситуації [17]; 18) комплексний метод навчання, який дає змогу будувати навчальний процес, виходячи 3 інтересів студентів, що дає можливість студенту виявити самостійність у плануванні, організації та контролі своєї навчально-пізнавальної діяльності, результатом якої є створення певного продукту чи явища (Г. Сазоненко); 19) цілеспрямована самостійна діяльність, здійснювана під гнучким керівництвом викладача, націлена на розв'язання творчої, дослідницької, соціально значущої проблеми і на отримання конкретного результату у вигляді матеріального i/aбо ідеального продукту (В. Коханова).

Розрізняють велику кількість різних типів проектів за низкою кваліфікаційних ознак відповідно до мети, ступеня комплексування із суміжними галузями, кількістю виконавців, тривалості тощо. До таких, що можуть використовуватись у медичних навчальних закладах, можна віднести: дослідницькі, пошукові, прикладні, рольові, інформаційні, монопроекти (у межах однієї галузі знань), особистісні, групові, коротко-, середньо-, довготривалі.

Основним завданням цього методу є: передати певний обсяг знань, навчити здобувати інформацію самостійним пошуком, аналізувати з різних точок зору та різні точки зору на цю проблему, систематизувати, робити висновки. Якщо проект колективний, студенти набувають ще і певних комунікативних навичок, вчаться працювати в команді.

Обов'язкові вимоги до такої форми роботи: проект розробляється з ініціативи студентів, які працюють над однією темою, а реалізують по-різному (чи за різними напрямами); необхідна чітко продумана структура, мета (початкова, проміжна, кінцева).

Роль викладача є особливою, оскільки він виступає координатором, тому повинен розробити послідовну концепцію, добре орієнтуватись в інформаційному матеріалі, мати високий професійний рівень.

Проектна робота тісно пов'язана 3 аудиторними заняттями, на яких студенти вивчають граматичний матеріал, засвоюють медичну термінологію, передбачену навчальною програмою, навчаються працювати з оригінальними англомовними медичними джерелами, формують навички мовлення, навчаються брати участь у бесіді. Тільки після такої підготовки студент може розпочати працювати над проектом.

При застосуванні методу проектів, особливо у студентів старших курсів медичного навчального закладу, існує також необхідність в інтеграції різних предметів. Міждисциплінарні зв'язки вирішують наявне протиріччя між розрізненим засвоєнням знань і необ- 
хідністю їх синтезу, комплексного запровадження у практиці, професійній діяльності лікаря. 3 позицій сучасних вимог до змісту освіти, спеціаліст повинен володіти вміннями іпрофесійною мобільністю, оперативно реагувати на постійні зміни у практичній діяльності.

Серед численних форм проблемного навчання можна запропонувати студентам форму міждисциплінарного семінару. Семінари належать до активних форм навчання, сприяють формуванню вміння самостійно засвоювати знання, аналізувати, синтезувати, абстрагувати, конкретизувати, узагальнювати; розвивають увагу, мислення, інтерес до навчального предмета. Семінари складаються 3 двох взаємопов'язаних ланок - самостійного вивчення студентами матеріалу та обговорення результатів їх самостійної пізнавальної діяльності [18]. Міждисциплінарний семінар є найскладнішим типом семінару, головне завдання якого - забезпечити усвідомлення студентами міжпредметних зв'язків, систематизувати знання, навички та вміння, підбити підсумки роботи. Міжпредметні зв'язки, структурно-логічні схеми спеціальностей, тобто зв'язки з іншими науками, дають змогу краще пізнати факти, явища та процеси, значною мірою сприяють усвідомленню місця того чи іншого навчального курсу в системі наук, спектри його розвивального впливу на підготовку лікаря. При цьому ставляться освітні цілі:

- навчальні цілі: а) набути нових вмінь, використовуючи міжпредметну інтеграціюй отримані теоретичні знання на різних кафедрах у процесі самостійної підготовки інформаційно-пошукового проекту; б) шляхом вирішення теоретичних і практичних проблем вдосконалити навички студентів при роботі з хворими з урахуванням особливостей перебігу хвороби, наявної супутньої патології та можливих ускладнень; в) на основі усвідомлення значення міжпредметних зв'язків для ефективної та успішної роботи, особливо лікаря-початківця, поглибити вміння студентів надавати адекватну допомогу хворим на різних етапах лікувального процесу;

- розвивальні цілі: а) розвинути здатність студентів до логічного мислення у вирішенні проблемних завдань; б) сприяти формуванню у студентів вміння самостійно засвоювати знання, аналізувати, синтезувати, абстрагувати, конкретизувати, узагальнювати набуті знання; в) спонукати студентів до колективного творчого обговорення найбільш складних питань, активізувати їх до самостійного вивчення наукової та методичної літератури; г) сприяти формуванню у студентів комунікативних навичок; - виховні цілі: а) розвинути у студентів професійну ініціативність, самостійність і відповідальність за якість надання допомоги хворим залежно від умов та етапу лікування; б) підготувати студентів до самостійної роботи з хворими;

- діагностично-корекційна мета: виявити й подолати можливі недоліки у засвоєнні студентами отриманих раніше знань, навичок і вмінь.

Висновок щодо педагогічної ефективності даної інтерактивної технології навчання. Ми вважаємо, що міждисциплінарний проект, будучи інтерактивним методом навчання, має позитивні та негативні сторони.

Переваги методу проектів: 1. Студенти активно набувають нових вмінь, використовуючи міжпредметну інтеграцію та отримані теоретичні знання на різних кафедрах у процесі самостійної підготовки інформаційно-пошукового проекту. 2. Студенти повністю занурюються у процес навчання згідно з їхніми потребами, інтересами і можливостями та шляхом вирішення теоретичних і практичних проблем вдосконалюють навички роботи 3 хворими. 3. Студенти навчаються надавати адекватну допомогу хворим на різних етапах лікувального процесу як у стандартних випадках, так і в унікальних, нестандартних ситуаціях. 4. Студенти набувають здатності самостійно розв'язувати проблему, та незалежно приймати рішення. 5. Студенти мають змогу поділитися власним досвідом 3 іншими студентами. 6. Ще під час навчання студентів цей метод розвиває професійний досвід, який полягає у професійній ініціативності, самостійності й відповідальності за якість надання допомоги хворим залежно від умов та етапу лікування. 7. Метод розвиває соціальні якості студентів, виховує відповідальність.

Проте даний метод має низку обмежень у застосуванні: 1. Потребує багато часу. 2. Важко завершити проектну програму в обмежений проміжок часу. 3. Не всі теми предмета можливо вивчати, використовуючи дану технологію. 4. Потребує великої кількості різноманітних матеріалів для виконання.

Тому ми вважаємо, що даний метод більш доречний для використання у середовищі студентів-старшокурсників, субординаторів, лікарів-інтернів. Практично орієнтований випускний іспит повною мірою $є$ відображенням методу проектів. Однією із мотиваційних складових могла б бути рекомендація проведення таких семінарів, як конкурсні для визначення претендентів у магістратуру чи резидентуру. Саме застосування методу проектів, який грунтується на міждисциплінарній інтеграції, сприяє засвоєнню одразу комплексу знань, які мають ступінчастий скріплений зв' язок, сприяє формуванню фахівця, здатного швидко реалізувати набуті знання на практиці. 


\section{Лiтература}

1. Демчук О. Метод проектів як особистісно-зорієнтована технологія розвитку життєвої компетентності / О. Демчук // Освіта регіону. Політологія, психологія, комунікації. -2011. - № 2. - С. 287-290.

2. Ящук С. М. Розвиток творчого потенціалу учнів у процесі проектно-технологічної діяльності / С. М. Ящук // Рідна школа. - 2004. - № 4. - С. 9-11.

3. Башинська Т. Проектувальна діяльність-основа взаємодії вчителя та учнів / Т. Башинська //Дайджест педагогічних ідей та технологій. -2003. -№ 3.-С. 49-52.

4. Сасова И. Через проблему - к практическому результату / И. Сасова // Учитель. - 2001. - № 5. - С. 35-38.

5. Пилюгина С. Метод проектной деятельности в Интернете и его развивающие возможности / С. Пилюгина // Школьные технологии. - 2002. - № 2. - С. 196-199. 6. Васин Е. К. Подготовка учащихся к выполнению проекта / Е. К. Васин // Школа и производство. -2003. - № 7. -С. 68 71.

7. Новые педагогические и информационные технологии в системе образования / [Е. Полат, М. Бухаркина, М. Моисеева, А. Петров]; под ред. Е. Полат. - М. : Академия, 2000. $-271 \mathrm{c}$.

8. Леонтьева М. Р. Об использовании метода проектов в образовательной области “Технология” / М. Р. Леонтьева // Школа и производство. - 2000. - № 6. - С. 6-8.

9. Методика трудового навчання : проектно-технологічний підхід. Навчальний посібник / за заг. ред. О. М. Кобер- ника, В. К. Сидоренко. - Умань : СПД Жовтий, 2008. -216 с.

10. Галустов Р. А. Творческие проекты студентов ТЭФ / Р. А. Галустов, Н. И. Зубов ; под ред. Р. А. Галустова. Брянск : Издательство БГПУ, НМЦ “Технология”, 1999. $152 \mathrm{c}$.

11. Хуторской А. В. Современная дидактика : учебник для вузов / А. В. Хуторской. - СПб. : Питер, 2001. - 544 с.

12. Баханов К. О. Інноваційні системи, технології та моделі навчання історії в школі : монографія / К. О. Баханов. Запоріжжя : Просвіта, 2004. -328 с.

13. Мацкевич Т. А. Педагогические технологии в развитии детей / Т. А. Мацкевич, Л. Г. Лукоянова // Негосударственное образовательное учреждение школа “Творчество" : опыт становления и тенденции развития / сост. Т. А. Мацкевич, А. П. Шевченко.-Самара, 2001.-С. 61-69.

14. Robert T. Howell. The Importance of the Project Method in Technology Edu-cation / Robert T. Howell // Journal of Industrial Teacher Education. - 2003. - Vol. 40, № 3 .

15. Чечель И. Д. Метод проектов : субъективная и объективная оценка результатов / И. Д. Чечель // Директор школы. - 1998. - № 4. - С. 3-10.

16. Рогачева Е. Ю. Педагогика Дж. Дьюи в контексте разных культур / Е. Ю. Рогачева // Педагогика. - 2003. - № 8.

17. Полат Е. С. Метод проектов : история и теория вопроca / Е. С. Полат // Школьные технологии. -2006. - № 6. - С. 43-47. 